\title{
Determinants of Capital Structure in Pakistani Listed Firms (The Case of Pakistani Listed Firms)
}

\author{
Khan S1, Ullah S1, ur Rehman I ${ }^{2}$, Sami I ${ }^{3}$, Ullah \\ $\mathrm{F}^{4 *}$, Salim $\mathbf{M}^{\mathbf{5}}$ and Ali $\mathrm{S}^{5}$ \\ ${ }^{1}$ Institute of Business and Management Sciences, The \\ Agricultural University, Peshawar, KPK, Pakistan \\ ${ }^{2}$ School of Marxism, China University of Geo Sciences \\ (Wuhan), Hongshan District Region Wuhan, P.R. China \\ ${ }^{3}$ Department of Finance and Management Sciences, \\ LUAWMS, Uthal Balochistan, Pakistan \\ ${ }^{4}$ Faculty of Veterinary and Animal Sciences, LUAWMS, \\ Uthal, Balochistan, Pakistan \\ ${ }^{5}$ Department of Forestry and Wildlife Management, \\ University of Haripur, Khyber, Pakhtunkhwa, Pakistan \\ *Corresponding author: Farman Ullah, Faculty of \\ Veterinary and Animal Sciences, National Center for \\ Livestock Breeding Genetics and Genomics LUAWMS, \\ Uthal, Balochistan, Pakistan
}

Received: April 02, 2021; Accepted: April 22, 2021; Published: April 29, 2021

\section{Introduction}

The capital structure decision is one of the most important decisions for financial management. The capital structure decision is at the center of many other decisions in the area of corporate finance. These include dividend policy, project financing, Issue of long-term securities, financing of mergers and buyouts and so on. One of the many objectives of corporate financial manager is to ensure the lower cost of capital and thus maximize the wealth of Shareholders. Capital structure is one of the effective tools with management to manage the cost of capital. An optimal capital Structure is reached at the point where the cost of the capital is minimum. Whether or not such an optimal capital structure exists? These are the potential determinants of such optimal capital structures. These are the questions to be answered by a researcher.

In other words, the job of researcher is to identify the potential determinants of capital structure in a given institutional settings, Industries and/or capital markets. The corporate financial managers thus can benefit from this to make an optimal mix of debt and equity in order to minimize the cost of capital. A large body of theoretical and empirical studies has focused on the area of capital structure since the path-breaking paper on capital structure by Miller and Modigliani published in 1958 [1]. To measure capital structure is an important practiced in field of business like Jensen and Meckling [2], De Angeloand Masulis [3], Amihud and Lev [4], Grossman and Hart [5], Myers and Majluf [6], Jensen [7], Harris and Revive [8], Stulz [9], Cheung and Krinsky [10] and Ross [11]. However, most of the research work has been carried out in developed countries with little work on capital structure of firms in developing economies. Pakistan is an emerging market with three stock exchanges, the Karachi Stock Exchange (KSE) being the largest one. More than 700 companies are listed on KSE. Little empirical work in the area of capital structure has been done in Pakistan. Limited research work exists on this area according to a study [12] on 10-developing countries including Pakistan. The purpose of this thesis was to explore determinants of capital structure in more detail including various sectors of Pakistan's economies. Pakistan is an emerging market with three stock exchanges, the Karachi Stock Exchange (KSE) being the largest one. More than 700 companies are listed on KSE. Little empirical work in the area of capital structure has been done in Pakistan. Limited research Work exists on this area. For example, Booth et al. [12] studied 10 developing countries including Pakistan. However, this study was confined only to top 100 index companies. Another study by Shah and Hijazi [13] was an improvement on the first one as it included all non-financial firms listed on KSE for the period 19972001. A study by Shah and Khan (2007) greatly improved upon the earlier work by Shah and Hijazi [13] as they included all non-financial firms listed on KSE and used superior econometric methodology to explore determinants of capital structure in the Pakistan's capital market. The purpose of this study was to explore determinants of capital structure in more detail including various sectors of Pakistan's economy.

In recent years, a number of theories have been proposed to explain the variation in debt ratios across firms. The theories suggest that firms select capital structures depending on attributes that determine the various costs and benefits associated with debt and equity financing. Empirical work in this area has lagged behind the theoretical research, perhaps because the relevant firm attributes are expressed in terms of abstract concepts that are not directly observable. The basic approach taken in previous empirical work has been to estimate regression equations with proxies for the unobservable theoretical attributes. This approach has a number of problems. First, there may be no unique representation of the attributes we wish to measure. There are often many possible proxies for a particular attribute, and 
Table 1: Means of selected variables by industries.

\begin{tabular}{|c|c|c|c|c|c|c|c|c|}
\hline & Textile & Chem & Eng & Sugar & Paper & Power & Cement & Misc. \\
\hline Leverage(LG) & 0.723 & 0.505 & 0.698 & 0.601 & 0.618 & 0.662 & 0.596 & 0.663 \\
\hline Profitability (PF) & -0.014 & 0.049 & -0.029 & -0.012 & 0.040 & 0.055 & -0.015 & 0.000 \\
\hline Tax Rate (TR) & 0.761 & 2.493 & 1.212 & 0.836 & 0.903 & 1.059 & 1.171 & 1.297 \\
\hline Tangibility (TG) & 0.552 & 0.393 & 0.351 & 0.613 & 0.463 & 0.386 & 0.655 & 0.384 \\
\hline Size (SZ) & 6.290 & 6.239 & 6.091 & 6.593 & 5.329 & 8.696 & 7.189 & 5.860 \\
\hline Growth (GT) & 0.074 & 0.084 & 0.072 & 0.066 & 0.062 & 0.129 & 0.067 & 0.086 \\
\hline
\end{tabular}

researchers, lacking theoretical guidelines, may be tempted to select those variables that work best in terms of statistical goodness-of-fit criteria, thereby biasing their interpretation of the significance levels of their tests. Second, it is often difficult to find measures of particular attributes that are unrelated to other attributes that are of interest. Thus, selected proxy variables may be measuring the effects of several different attributes. Third, since the observed variables are imperfect representations of the attributes they are supposed to measure, their use in regression analysis introduces an errors-in-variable problem. Finally, measurement errors in the proxy variables maybe correlated with measurement errors in the dependent variables, creating spurious correlations even when the unobserved attribute being measured is unrelated to the dependent variable.

\section{Materials and Methods}

The sample data was comprised of non-financial firms listed on Karachi Stock Exchange, Pakistan from 1993 to 2002. We were excluded all firms in financial sector from our analysis as the capital structures of these firms are not comparable to the capital structures of firms in non-financial sector. Specifically, we excluded banks, insurance companies, and investment companies. This section discuss the dependent variable and independent variables. We were taken the debt to total assets ratio as a proxy for leverage (dependent variable) that was measured following ways mentioned highlighted in several research studies e.g. Titman and Wessels [14], Rajan and Zingales [15] and Banerjee et al. [16]. For potential determinants of leverage, we study four independent variables namely tangibility (a firm with higher percentage of fixed assets will have higher debt ratio), size (there is negative relationship between size and leverage of the firm), growth (firm with higher growth rate will have lower leverage) and profitability (firm with higher profitability will have lesser leverage).

\section{Results and Discussion}

The report was descriptive statistics for various variables used in this study for analyzing the determents of capital structure for the Pakistani firms in Table 1. The statistic reported in the Table 1 indicates that leverage ratio is highest for textile sector. It is followed by engineering textile industry is relatively more capital intensive. This could be one reason for higher leverage ratio.

Methodology: This Study uses the following model to analyze the determinants of capital structure for Pakistani firms:

$\mathrm{LG}_{\mathrm{it}}=\beta_{0}+\beta_{1}\left(\mathrm{TG}_{\mathrm{it}}\right)+\beta_{2}\left(\mathrm{SZ}_{\mathrm{it}}\right)+\beta_{3}\left(\mathrm{GT}_{\mathrm{it}}\right)+\beta_{4}\left(\mathrm{PF}_{\mathrm{it}}\right)+\beta_{5}\left(\mathrm{TR}_{\mathrm{it}}\right)+\varepsilon$

Whereas.

$\mathrm{LG}=$ Leverage
$\mathrm{TG}=$ Tangibility of assets

$\mathrm{SZ}=$ Size

$\mathrm{GT}=$ Growth

$\mathrm{PF}=$ Profitability

$\mathrm{TR}=$ Tax Rate

$\varepsilon=$ The Error term

Empirical analysis

Table 2 reports results for the above regression model as reported in table, $\mathrm{R}^{2}$ shows that only $25.16 \%$ of the variations in leverage ratio are explained by the variations in independent variables. F-statistics shows that the overall model is valid.

As shown in Table 2, only four of the independent variables are significantly related to leverage. Profitability is negatively related to leverage and confirms fourth hypothesis. Tax rate, being negatively related to debt ratio. Tangibility is positively related to debt ratio and is in conformity with first hypothesis. The other two variables are not statistically significantly. This statistical insignificance can be inferred, as the P-Value is greater than the chosen $5 \%$ level of significance for the size (SZ) and growth (GT) co-efficient. It may indicate that the size of the firm cannot be an important determinant of leverage in case of Pakistani firms. This rejects the hypothesis 02 that larger firms have higher leverage ratios. Growth variable is also not significant. The co-efficient of growth is negative. Negative growth co-efficient indicate that growing firms do not use much of a leverage. This is in conformity with the hypothesis 03 , which states that growing firms will have lower leverage ratio.

Profitability is one of the important determinants of firm's leverage. The profitability co-efficient is negative, this negative profitability sign indicates the profitable firm's have more internal

Table 2: Regression Analysis of the model.

\begin{tabular}{|l|c|c|c|}
\hline \multicolumn{1}{|c|}{ Independent Variables } & Coefficient & t-Statistic & P-Value \\
\hline Leverage (LG) Intercept & 0.67642 & 29.3761 & 0.0000 \\
\hline Profitability (PF) & -0.734 & -19.730 & 0.000 \\
\hline Tax Rate (TR) & -0.032 & -10.950 & 0.000 \\
\hline Tangibility (TG) & 0.052 & 2.430 & 0.015 \\
\hline Size (SZ) & 0.000 & -0.060 & 0.948 \\
\hline Growth (GT) & -0.030 & -1.440 & 0.150 \\
\hline R Square & & 0.2516 & \\
\hline F-statistic & & 113.51 & \\
\hline Prob. (F-statistic) & & 0 & \\
\hline
\end{tabular}


funds at their disposal and these are less dependent on the external financing, and thus have lower leverage. The negative co efficient for the profitability factor is in line with the hypothesis 04 that firms with higher profitability have lower leverage ratio.

\section{Conclusion}

We used different variables to measure their effect on leverage ratio out of those three variables were significantly related to leverage ratio whereas the remaining three variables were not statistically significant in having relationship with the debt ratio. Our results approve the prediction of trade-off theory in case of tangibility variable whereas the growth (GT) variable confirms the agency theory hypothesis whereas profitability $(\mathrm{PF})$ approves the predictions of pecking order theory. Size (SZ) variable confirms neither to the prediction of trade-off theory nor to asymmetry of information theory.

\section{Acknowledgement}

The Agricultural University, Peshawar KPK, supported present study: Pakistan and credit for preparation of this manuscript goes to author and co-authors.

\section{References}

1. Modigliani F and MH Miller. The cost of capital, corporation finance and the theory of investment. American Economic Review. 1958; 48: 261.

2. Jensen $\mathrm{C}$ and William $\mathrm{H}$ Mecking. Theory of the Firm: Managerial Behaviour Agency Costs and Ownership Structure. Journal of Financial economics. 1976; 3: 305-360.

3. De Angelo $\mathrm{H}$ and RW Mausulis. Optimal capital structure under corporate and personal taxation. Journal of Financial Economics. 1980: 3-29.

4. Amihud $Y$ and $B$ Lev. Risk reduction as a managerial motive for conglomerate mergers. Bell Journal of Economics. 1981: 12: 605-616
5. Grossman $\mathrm{S}$ and $\mathrm{O}$ Hart. Corporate financial structure and managerial incentives, in John McCall ed., The Economics of Information and Uncertainty University of Chicago Press, Chicago, IL. 1982.

6. Myers S and N Majluf. Corporate financing and investment decisions when firms have information investors do not have. Journal of Financial Economics. 1984; 13: 187-222.

7. Jensen M. Agency costs of free cash flow, corporate finance and takeovers. American Economics Review. 1986; 76: 323-329.

8. Harris M and A Raviv. Capital Structure and the Informational Role of Debt Journal of Finance. 1990; 45: 321-349.

9. Stultz R. Managerial discretion and optimal financing policies. Journal of Financial Economics. 1990; 26: 3-27.

10. Cheung CS and Itzhak Krinsky. Information asymmetry and the underpricing of Initial public offerings:further empirical evidence. Journal of Business Finance and Accounting. 1994; 21: 739-747.

11. Ross SA. The Determination of financial structure: the incentive signaling approach. Bell Journal of Economics. 1977: 23-40.

12. Booth L, V Aivazian, A Demirguc-Kunt, and V Maksmivoc. Capital structures in developing countries". Journal of Finance. 2001; 56: 87-130.

13. Shah A and T Hijazi. The determinants of capital structure of stock exchangelisted non-financial firms in Pakistan. Pakistan Development Review. 2004; 43: $605-618$

14. Titman $S$ and $T$ Wessels. The determinants of capital structure choice. Journal of Finance. 1988; 43: 1-19.

15. Rajan R and L Zingales. What do we know about capital structure? Some evidence form international data". Journal of Finance. 1995; 50: 1421-1460.

16. Banerjee S, A Hesmati and C Wihlbortg. The dynamics of capital structure. SSE/EFI Working Paper Series in Economics and Finance. 2000; 333: 1-20. 